\title{
REFLEKSI SISTEM NILAI MASYARAKAT PESISIR PADANG SEURAHET DI GAMPONG BLANG BEURANDANG KABUPATEN ACEH BARAT
}

\author{
Arfriani Maifizar $^{1}$, Nurhaslita $^{2}$, Afrizal Tjoetra $^{3}$, Sutikno $^{4}$, Muhammad Fadhal $^{5}$ \\ Prodi Sosiologi Universitas Teuku Umar ${ }^{1,3}$ \\ $\underline{\text { arfrianimaifizar@utu.ac.id }}^{1}$, afrizaltjoetra@utu.ac.id $^{3}$ \\ Prodi Administrasi Universitas Teuku Umar ${ }^{2}$ \\ $\underline{\text { nurhaslita.sari@utu.ac.id }}^{2}$ \\ Prodi Pendidikan Bahasa dan Sastra Indonesia ${ }^{4}$ \\ Universitas Muslim Nusantara Al-Washliyah Medan \\ sutikno@umnaw.ac.id $^{4}$ \\ Mahasiswa Magister Sosiologi Universitas Sumatera Utara ${ }^{5}$ \\ fadha115111994@gmail.com ${ }^{5}$
}

\begin{abstract}
*
The Aceh coastal community is a community that lives in the area of Aceh Province and inhabits the coastal area as a place of residence that is believed to be suitable for socializing. Most of the people earn their livelihood as fishermen. The life needs of the people of this area are obtained from coastal natural resources which are dominated by fisheries. The economic, cultural, educational and religious value systems are an interesting part to conduct an in-depth study of the sociological aspects. This research was carried out in Blang Beurandang Village with a focus on key informants from the Padang Seurahet community who inhabited relocation housing in West Aceh District. Research conducted using this qualitative approach focused more on purposive sampling techniques in determining informants. This is done in order to achieve the expected data. The results of this study indicate the local wisdom of the people of Padang Seurahet are able to play an active role in managing nature and its potential such as quality of life, environmental quality despite having a variety of different professions. The need for hard work from village village officials in the field of education to change the mindset of local communities, especially the younger generation in mastering technology and following the development of science. Improvement of Religion and Models of economic development, the environment, and strengthening community and management capacity in managing natural resources in accordance with the potential and local wisdom towards a more independent life.
\end{abstract}

Keywords: Value system, Community, Fishermen, The coast

\section{PENDAHULUAN}

Masyarakat pesisir adalah sekelompok warga yang tinggal di wilayah pesisir yang hidup bersama dan memenuhi kebutuhan hidupnya dari sumber daya alam di wilayah pesisir.Demikian pula jenis mata pencaharian yang memanfaatkan sumber daya 
Community: Volume 6, nomor 1, April 2020

p-ISSN: 2477-5746 e-ISSN: 2502-0544

alam atau jasa-jasa lingkungan yang ada di wilayah pesisir seperti nelayan, petani ikan, dan pemilik atau pekerja industri maritim.Masyarakat pesisir yang di dominasi oleh usaha perikanan pada umumnya masih berada pada garis kemiskinan, mereka tidak mempunyai pilihan mata pencaharian, disebabkan memiliki tingkat pendidikan yang rendah, tidak mengetahui dan menyadari kelestarian sumber daya alam dan lingkungan.

Wilayah pesisir didefinisikan sebagai wilayah daratan yang berbatasan dengan laut, batas di daratan meliputi daerah-daerah yang tergenang air maupun yang tidak tergenang air yang masih dipengaruhi oleh proses-proses laut seperti pasang surut, angin laut dan intrusi garam, sedangkan batas di laut ialah daerah-daerah yang dipengaruhi oleh proses-proses alami di daratan seperti sedimentasi dan mengalirnya air tawar ke laut, serta daerah-daerah laut yang dipengaruhi oleh kegiatan-kegiatan manusia di daratan. Masyarakat pesisir pantai terkenal dengan perwatakannya yang sangat keras.Ini bukan tanpa sebab, tetapi dikarenakan pola hidup mereka yang sangat tergantung dengan alam.Karakter masyarakat pesisir biasanya keras,berani,dan berjiwa petarung. Hal ini dikarenakan masyarakat yang dinggal di dalam kawasan pantai/pesisir lebih mengutamakankeberanian dalam mencari nafkah rezekinya walaupun tantangannya adalah taruhan hidup mereka sendiri.

Secara sosiologis, karakteristik masyarakat nelayan berbeda dengan krakteristik masyarakat petani, seiring dengan perbedaan karakteristik sumber daya yang dihadapi. Masyarakat petani menghadapi sumber daya terkontrol, yakni pengelolaan lahan untuk produksi suatu komoditas dengan output yang relatif bisa diprediksi. Dengan sifat produksi yang demikian memungkinkan tetapnya lokasi produksi sehingga menyebabkan mobilitas usaha yang relatif rendah dan elemen risiko pun tidak besar. Karakteristik tersebut berbeda sama sekali dengan nelayan. Nelayan menghadapi akses sumber daya yang hingga saat ini masih bersifat openaccess. Karakteristik sumber daya seperti ini menyebabkan nelayan mesti berpindahpindah untuk memperoleh hasil maksimal, yang dengan demikian elemen risiko menjadi sangat tinggi. Kondisi sumber daya yang berisiko tersebut menyebabkan nelayan memiliki karakter keras, tegas, dan terbuka (Satria, 2009).

Masyarakat Pesisir pada umumnya memiliki ciri khas dalam kegiatan upacaraupacara kebudayaan ataupun yang berhubungan dengan kearifan lokal tempatan. Kekhasan itu tentunya dipandu oleh kebudayaan pesisir yang berbeda dengan masyarakat pedalaman. Di antara kegiatan yang menonjol, terutama yang dikaitkannya dengan Islam, ialah ciri masyarakat pesisir yang adaptif terhadap ajaran Islam disbanding dengan masyarakat pedalaman yang sinkretik. Budaya adaptif tersebut tampak dalam performance tradisi lokal yang dipandu dan dipedomani oleh Islam yang coraknya yang mengambil ajaran Islam sebagai kerangka seleksi terhadap budaya lokal dan bukan mengambil yang relevan bagaimana budaya pedalaman (Syam, 2005). 
Gampong Padang Seurahet merupakan salah satu gampong yang berada di dalam wilayah Gampong Blang Beurandang. Blang beurandang merupakan daerah relokasi bagi para korban bencana tsunami.Selain Gampong Padang Seurahet ada beberapa komunitas Gampong lainnya yang mendiami Blang Beurandang, Kesemua komunitas kelompok masyarakat berasal dari pendatang.Pada kenyataannya terjadi Asimilasi karakter komunitas padang seurahet, pendatang dengan masyarakat asli Gampong Blang Beurandang. Dalam pencapaiannya sekarang ini, kehidupan sosial masyarakat Padang Seurahet yang berasal dari komuitas masyarakat pesisir mulai mampu berbaur dengan

Masyarakat asli Blang Beurandang yang merupakan masyarakat perdesaan.Akan tetapi dalam hal budaya dan karakteristik kehidupan sehari-hari, masyarakat Padang Seurahet tetap mempertahankan identitasnya sebagai masyarakat pesisir. Oleh karenanya penelitian ini sangat menarik untuk dilakukan kajian secara mendalam mengenai refleksi sistem nilai mengetahui kajian secara mendalam berkaitan dengan Sistem nilai kearifan lokal dan identitas yang dipertahankan oleh masyarakat pesisir padang seurahet yang bertempat tinggal di daerah relokasi Blang Beurandang.

\section{TINJAUAN PUSTAKA}

\subsection{Sistem Nilai}

Setiap masyarakat dapat dipastikan memiliki sistem nilai, karena sistem nilai melekat pada budaya yang dimiliki oleh masyarakat, sedangkan tidak ada satupun masyarakat yang tidak berbudaya (Ihromi, 2006). Pada masyarakat yang memiliki budaya Agama tertentu, maka sistem nilai juga akan mengikuti nilai-nilai dalam agama yang dianutnya, meskipun dalam beberapa hal ini ditengarai nilai agama tidak diadopsi secara totalitas. Bahkan juga sering agama atau budaya lain turut mempengaruhi.

Sistem nilai merupakan satu kesatuan dari nilai-nilai yang saling berhubungan atau hubungan diantara hubungan yang digunakan oleh suatu masyarakat (Ritzer, 2010). Nilai-nilai dimaksud merupakan pembentuk norma-norma yang ada dalam masyarakat dan merupakan kesepakatan warga masyarakat baik langsung atau tidak langsung. Berikutnya norma-norma ini yang akan digunakan sebagai pengatur tingkah laku warga masyarakat. Untuk itu diperlukan berbagai macam norma mengikuti kebutuhan manusia sebagai warga masyarakat.

Koentjaraningrat menyebutkan norma sebagai pranata sosial, dimana pranata yang ada dapat diklasifikasikan sekurang-kurangnya dalam 8 (delapan) golongan, yaitu untuk memenuhi berbagai macam kebutuhan seperti: a). Kehidupan kekerabatan, b). Mata pencaharian hidup, c). Pendidikan, d). Ilmiah manusia untuk menyelami alam semesta e). Kenyamanan hidup manusia, f).Mengelola keseimbangan dan kekuasaan, g).Berhubungan dan berbakti kepada Tuhan, h). Menghayati keindahan dan rekreasi (Koentjaraningrat, 2009). 
Community: Volume 6, nomor 1, April 2020

p-ISSN: 2477-5746 e-ISSN: 2502-0544

Inti dari yang disampaikan Koentjaraningrat di atas adalah bahwa setiap kebutuhan manusia memerlukan aturan sehingga masyarakat bertindak dan berperilaku mengikuti norma yang berlaku. Dengan demikian normalnya setiap masyarakat akan menghindari perbuatan yang dilarang dan menjalankan hal-hal yang diperbolehkan dan dianggap baik menurut masyarakat. Bahkan norma yang berlaku dalam masyarakat ini juga diperkuat oleh religi yang dianut masyarakat tersebut. Pada sisi yang lain, pada beberapa masyarakat sering penerapan nilai-nilai agama juga sering didampingi oleh adat tradisi yang dimiliki masyarakat itu sendiri (Wahyuni, 2011).

Adat tradisi yang mendampingi nilai-nilai agama ini yang kemudian juga memberikan kebudayaan yang berbeda-beda meskipun agama masyarakat sama namun memiliki adat yang berbeda. Perbedaan adat dan tradisi sering terwujud dan tampak pada perbedaan etnik dan juga geografi dimana masyarakat menempati. Dengan demikian berlakunya sistem nilai juga akan berbeda-beda (Wahyuni, 2011). Penekanannya adalah bahwa sistem nilai yang berlaku pada setiap masyarakat bisa jadi berbeda-beda meskipun perbedaan itu kecil. Akan tetapi terkadang dalam suatu area/ daerah memiliki adat tradisi atau budaya yang sama meskipun secara etnis berbedabeda.

\subsection{Perspektif Teori Struktural Fungsional}

Penelitian ini penulis menggunakan teori struktural fungsional berdasarkan paradigma fakta sosial (Ritzer G. , 1992). Secara sosiologis pusat perhatian dari paradigma ini adalah fakta-fakta sosial. Untuk diketahui bahwa fakta sosial terdiri atas dua tipe yaitu struktur sosial dan pranata sosial. Struktur sosial adalah jaringan hubungan sosial yang memungkinkan interaksi sosial berproses dan terorganisasi. Melalui struktur sosial tersebut posisi-posisi sosial dari individu dan sub kelompok dapat dibedakan. Pranata diartikan sebagai seperangkat aturan yang digunakan secara aktual oleh sekumpulan individu untuk mengorganisasikan tindakan yang berulangulang, yang menghasilkan suatu keluaran yang mempengaruhi individuindividu tersebut, dan juga potensial mempengaruhi orang lain.

Dengan kata lain, pranata adalah seperangkat aturan yang berlaku atau digunakan yang dijadikan sebagai acuan untuk bertindak. Adapun fokus penelitian ini adalah tentang sistem nilai kearifan lokal masyarakat pesisir baik dengan mata pencaharianmaupun dalam pengelolaan sumber daya pesisir secara keseluruhannya sehingga dapat mengetahui secara keseluruhan potret Sistem sosial yang di alami oleh masyarakat Padang Seurahet. Dalam hal ini nilai nilai lokal masyarakat pesisir Padang Seurahet merupakan pranata yang dapat menjembatani hubungan antara kegiatan masyarakat pesisir dengan lingkungan alamnya.

Hal ini karena nilai-nilai lokal berisi aturan yang berlaku atau digunakan dan dijadikan sebagai acuan masyarakat pesisir Padang Seurahet dalam bertindak. Dalam 
kaitannya dengan pengelolaan sumberdaya pesisir, nilai-nilai lokal masyarakat pesisir Padang Seurahet telah dijadikan acuan bagi masyarakat tersebut dalam mengelola sumberdaya pesisir. Nilai-nilai lokal adalah sistem yang menghubungkan kelompok manusia terhadap pengaturan lingkungan mereka. Nilai-nilai lokal masyarakat pesisir memiliki peran besar dan dapat mempengaruhi hubungan antara manusia dengan lingkungannya. Nilai-nilai lokal tersebut dapat berperan dalam menjaga kondisi keseimbangan hubungan antara manusia dan sumberdaya pesisir.

\section{METODE PENELITIAN}

Penelitian ini dilakukan dengan pendekatan kualitatif. Hal ini dipilih untuk mendapatkan data yang jauh lebih dalam bahkan tersembunyi dalam pemikiran dan perasaan masyarakat.Pemilihan tempat penelitian ini dilakukan di Gampong Blang Beurandang di Aceh Barat. Gampoeng ini memiliki beberapa hal yang sangat menarik untuk dipilih mengenai terbentuknya sistem nilai sosial dikarenakan perpaduannya masyarakat asli dengan masyarakat relokasi Padang Seurahet.

Pemilihan informan dilakukan dengan menggunakan teknik purposive sampling yang lebih menitikberatkan atas pertimbangan-pertimbangan tertentu agar dapat tercapai data yang diharapkan. Banyak sedikitnya informan sangat relatif dengan data yang diperoleh.Untuk itu, Bungin menyebutkan ada beberapa langkah dalam menentukan informan sebagai sampel ini, yakni; a).pemilihan sampel awal baik untuk observasi maupun wawancara, b). pemilihan sampel lanjutan untuk mendapatkan variasi data yang mungkin ada, dan c). menghentikan pemilihan sampel jika sudah tidak ditemukan variasi data lagi (Bungin, 2012).

Tujuan penelitian adalah untuk membuat deskripsi, gambaran atau lukisan secara sistematis, faktual, dan akurat mengenai fakta-fakta, sifat-sifat serta hubungan antar fenomena yang diselidiki (Emzir, 2009) .Adapun Sasaran yang ingin dicapai dalam penelitian ini yaitu mengidentifikasikan dan mampu mendeskripsikan Refleksi Sistem Nilai Sosial Masyarakat Pesisir Padang Seurahet Di Gampong Blang Beurandang Kabupaten Aceh.

\section{TEMUAN DAN PEMBAHASAN}

A. Gambaran singkat Gampong Padang Seurahet

Gampong Padang Seurahet salah satu Gampong di kecamatan Johan Pahlawan Kabupaten Aceh barat,Padang seurahet merupakan salah satu desa/gampong yang telah dilululantakan oleh tsunami, mayoritas masyarakat padang seurahet adalah pendatang dari kabupaten Aceh Selatan, Aceh Barat Daya, Nagan Raya. Mata pencaharian masyarakat ialah laut, dimana dari hasil lautlah yang menjadi seumber pendapat ekonomi masyarakat padang seurahet, adapun dari hasil yang di dapat $70 \%$ masyarakat 
Community: Volume 6, nomor 1, April 2020

p-ISSN: 2477-5746 e-ISSN: 2502-0544

padang seurahet memiliki tingkat pendidikan yang hanya sampai pada jenjang Sekolah Menengah Atas (SMA) sedangkan 25\% lainya adalah penduduk padang seurahet yang saat ini masih menempuh pendidikan di tingkat perguruan tinggi, 5\% lainnya merupakan masyarakat padang seurahet yang telah menyelesaikan tingkat pendidikan strata 1 ( Sarjana).

Pasca Tsunami yang terjadi pada 26 Desember 2004 membuat banyak perumahan pada masyarakat padang seurahet itu sendiri hancur, dimana pada mulanya gampong padang seurahet terletak sangat dekat dengan lautan (pesisir) namun kini telah berpindah ke daerah datar yang dekat dengan kodisi hutan, sehingga dalam menuju tempat mata pencaharian masyarakat padang seurahet saat ini membutuhkan waktu +30 menit. Selain melakukan penjualan hasil laut yang didapat, masyarakat padang seurahet juga mengolah hasil laut itu menjadi beragam, seperti pembuatan Ikan Asin, Ikan kayu dan lainnya.

Gampong Padang Seurahet merupakan Gampong memiliki wilayah yang strategis (sebelum direlokasi) untuk areal perikanan dan perkebunan.Gampong Padang Seurahet berada di Kecamatan Johan Pahlawan dan berada dalam wilayah kabupaten Aceh Barat. Pusat ibu kota kecamatan terletak di Kota, dengan luas wilayah $\pm 17,8 \mathrm{Km}^{2}$ yang terbagi dalam 7 Jurong atau dusun, dengan jumlah penduduk 3.186 jiwa dari 650 kepala keluarga (KK), yang tersebar ke dalam 7 jurong tersebut. Gampong Padang Seurahet memiliki jarak ke ibu kota kabupaten $+1,2 \mathrm{Km}$ dan ke ibu kota kecamatan +4 km. Secara Topografi Gampong Padang Seurahet (wilayah gampong sekarang) dikelilingi oleh perkebunan dan persawahan rakyat, jika dilihat dari letak topografi Gampong Padang Serahet ini dominannya lebih banyak daerah lembah dan rawa. Adapun secara administratif, wilayah Gampong Padang Seurahet (sebelum direlokasi) berbatasan sebagai berikut :

1. Sebelah Utara berbatasan dengan Gampong Ujong Baroh.

2. Sebelah Timur berbatasan dengan Gampong Meureubo.

3. Sebelah Barat berbatasan dengan Gampong Pasar Aceh.

4. Sebelah Selatan berbatasan dengan Lautan Hindia.

Gampong ini di tempati oleh 3.186 jiwa penduduk.Gampong Padang Seurahet memiliki 7 (Tujuh) Dusun yaitu : Dusun satu, dusun dua, dusun tiga, dusun empat, dusun lima, dusun enam dan dusun tujuh. 


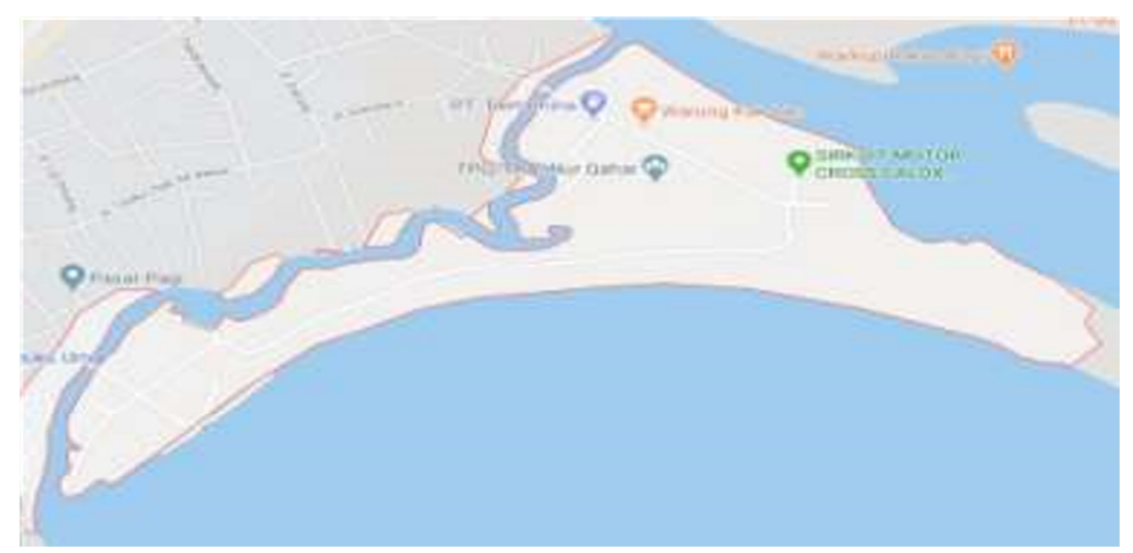

Sumber: (www.maps.google.co.id)

Gambar. 4.1 Maps Gampong Padang Seurahet

\section{B. Refleksi Sistem Nilai Sosial Masyarakat Padang Seurahet di Aceh Barat}

Kearifan lokal dan identitas yang masih dipertahankan oleh masyarakat pesisir Padang Seurahet yang bertempat tinggal di daerah tersebut, Mata pencaharian masyarakat ialah laut, dimana dari hasil lautlah yang menjadi seumber pendapat ekonomi masyarakat padang seurahet, adapun dari hasil yang di dapat $70 \%$ masyarakat padang seurahet memiliki tingkat pendidikan yang hanya sampai pada jenjang Sekolah Menengah Atas (SMA) sedangkan 25\% lainya adalah penduduk padang seurahet yang saat ini masih menempuh pendidikan di tingkat perguruan tinggi, 5\% lainnya merupakan masyarakat padang seurahet yang telah menyelesaikan tingkat pendidikan strata 1.

\section{Karakter Identitas sosial Budaya Masyarakat Padang Seurahet.}

Dalam pembahasan bersama tokoh aparatur gampong dapat disimpulkan bahwa mengenai karakter dan identitas masyarakat gampong Seurahet adalah masyarakat pesisir di Padang Seurahet merupakan masyarakat yang berpindah tempat, yang mana dulunya bertempat tinggal di wilayah pesisir atau dekat pantai. Pasca bencana Tsunami di akhir tahun 2004 berpindah tempat atau melakukan relokasi tempat tinggal berpindah ke wilayah pedesaan yang jauh dengan pantai yaitu di Blang Beurandang, akan tetapi identitasnya tetap sebagai masyarakat pesisir atau masyarakat Padang Seurahet.

Berkenaan dengan karakteristik pembahasan lebih lanjut dapat di analisis secara mendalam bahwa masyarakat pesisir di Padang Seurahet sebenarnya tidak memiliki karakter keras, pada dasarnya masyarakat pesisir ini sama juga dengan masyarakat pada umumnya hanya saja asumsi masyarakat yang menyatakan 
Community: Volume 6, nomor 1, April 2020

p-ISSN: 2477-5746 e-ISSN: 2502-0544

bahwasanya masyarakat pesisir itu berkarakter keras, disebabkan keadaan atau kondisi yang menjadikan masyarakat pesisir Padang Seurahet ini berkarakter keras.

Kondisi Alam saat menjalankan profesi nelayan diharuskan berada di tengah dilaut sehingga pendengaran para nelayan sedikit terganggu dengan gemuruhnya gelombang laut, karenanya di tuntut harus bersuara keras agar pendengarannya menjadi lebih jelas. kondisi inilah menjadikan salah satu faktor masyarakat pesisir dikatakan berkarakter keras, namun masyarakat Padang Seurahet akan beradaptasi dengan lingkungan tempat tinggalnya dan pada umumnya masyarakat ini mampu berperilaku dan berkarakter lemah lembut di lingkungan gampong tempat tinggalnya Blang Beurandang. Dengan Kondisi sosial tergambarkan diatas menunjukkan bahwa masyarakat di Padang Seurahet lambat laun sudah mulai melakukan suatu perubahan sistem nilai sosial dengan tidak menghilangkan identitas masyarakatnya.

Pendalaman identitas ini sangat mempengaruhi kehidupan sosial dan budayanya dalam mempertahankan adat budaya masyarakat pesisir Padang Seurahet. Walaupun tinggal di daerah relokasi, namun dalam beberapa tradisi tetap di pertahankan dengan tujuan melestarikan budaya pesisir, oleh karenanya masyarakat Padang Seurahet secara rutin melakukan beberapa ritual, diantaranya seperti : (a) Peusijuk Pawang Laut (b).Peusijuk Boot atau Perahu. (c). Kenduri Sebelum Turun ke Laut yang di pimpim oleh Pawang Laut. Dari Aspek Kepercayaan, masyarakat Padang Seurahet masih menganggap bahwa laut memiliki kekuatan yang luar biasa sehingga masyarakar Padang Seurahet sering melakukan adat pesta laut atau sedekah laut. Ritual pelepasan perahu kecil oleh pawang laut masih di sering dilakukan, Adat tidak bisa di hilangkan oleh masyarakat nelayan, karena itu adat istiadat tersebut telah menjadi turunan dari nenek moyang ebelum para nelayan berlayar ke lautan lepas.

Masyarakat Pesisir mendapat pengetahuan dari warisan nenek moyangnya mengenai kemampuan melihat fenomena alam, seperti ketika masyarakat nelayan ini mampu melihat kalender dan petunjuk arah perahu belayar dengan menggunakan rasi bintang. Walaupun tradisi dan adat budaya di pertahankan oleh masyarakat pesisir ,akan tetapi masih ada sebagian masyarakat dan generasi muda yang tidak mempercayai adat budaya seperti pesta laut tersebut.

\section{Perekonomian dan Pendapatan Masyarakat Padang Seurahet.}

Masyarakat Gampong Padang Seurahet menggantungkan perekonomian kepada hasil alam seperti menjadi nelayan. Namun setelah Tsunami perpindahan tempat tinggal ke daerah relokasi Blang beurandang menjadikan perubahan profesi dari mata pencaharian nelayan menjadi petani. Peralihan profesi ini tidak dapat dilakukan oleh sebagian besar Masyarakat Padang seurahet, mengingat sudah menjadi turun menurun 
berprofesi melaut atau sebagai nelayan,Hal ini sangat sulit dilakukan oleh Masyarakat Padang seurahet ketika diharusnya berganti profesi sebagai Petani.

Karena profesi petani membutuhkan proses waktu dalam bercocok tanam tentunya sangat bertolak belakang dengan karakter masyarakt nelayan yang menginginkan hasil pendapat yang instan dan cepat. Dalam proses pencarian pendapatan masyarakat Padang seurahet mempunyai dua musim melaut dalam satu tahun seperti musim barat dan musim timur . Masyarakat Padang Seurahet kebanyakan berpergian dalam melaut tepatnya pada musim timur, karena pada musim timur di peroleh penghasilan lebih sedikit daripada musim barat diakibatkan tersedianya ikan yang berjumlah sedikit di bandingkan musim barat. Musim barat akan menghasilkan pendapatan ekonomi yang meningkat bagi para nelayan.

Berkaitan dengan petrilaku masyarakat Padang Seurahet dalam mengelola hasil Pendapatan ekonomi juga sangat menarik di dalami, dimana ketika kebanyakan para Nelayan mudah mendapatakan uang dari hasil penjualan ikan maka para nelayan begitu mudah pula untuk menghabiskan dan bila pendapatan masih terkumpul dan memadai maka para nelayan tidak menjalankan profesi mencari ikan di laut selama beberapa hari kedepan.Perilaku sosial masyarakat pesisir Padang seurahet ini menjadi tolak ukur atas kemiskinan yang absolute.

Perbandingan Profesi Masyarakat Padang Seurahet sebagai Nelayan di laut lepas dengan Profesi petani di gampong Blang Berandang menjadi sisi menarik dalam kajian sosiologi karena Produktivitas kerja di sektor perikanan maupun pertanian akan menjadi dua profesi yang secara bersamaan dijalankan oleh masyarakat padang seurahet baik di tempat Asalnya Gampong Padang Seurahet Maupun di tempat tinggalnya Sekarang di Gampong Blang beurandang.

Kegiatan ini dilakukan dalam meningkatkan secara bertahap upaya-upaya dalam menciptakan kesempatan yang lebih luas dan produktif bagi masyarakat untuk mencari nafkah. Penghasilan yang diperoleh masyarakat Padang Seurahet ketika menjadi petani di Gampong Blang Beuradang berjumlah sama dengan pendapatannya sebagai Nelayan yang bergantung pada musim. Namun kebayakan masyarakat Padang Seurahet yang tinggal di gampong Blang Beuradang keberatan melakukan pengalihan profesi dari nelayan menjadi petani.

Alasan tidak ingin peralihan profesi ini oleh kebanyakan masyarakat padang seurahet dikarenakan asumsinya bahwa pendapatan yang di peroleh pada profesi nelayan lebih besar dan cepat daripada petani, walaupun hasil yang didapatkannya dipengaruhi dengan keadaan perubahan cuaca laut yang tidak menentu. Dalam hal ini Masyarakat Nelayan ini dalam mencukupi kehidupan social ekonominya selalu memperhatikan alam sekitarnya 
Community: Volume 6, nomor 1, April 2020

p-ISSN: 2477-5746 e-ISSN: 2502-0544

E. Pendidikan Masyarakat Padang Seurahet.

Sebahagian masyarakat Padang Seurahet tidak melanjutkan sekolah ke jenjang Universitas karena disebabkan faktor lingkungan, pola pikir, kemauan diri mereka sendiri dan ekonomi keluarga , karenanya generasi muda Padang Seurahet menempuh pendidikan hanya sampai pada strata sekolah menengah Atas (SMA) serta tidak lagi melanjutkan pendidikan ke bangku perkuliahan sekitar 30\% masyarakat pesisir di Padang Seurahet yang sekarang ini pendidikannya hanya sampai tingkat SMA. Fenomena social ini terjadi dalam tingkat Pendidikan khususnya bagi para remaja terjadi karena generasi muda menghabiskan waktunya untuk bekerja bermata pencaharian sebagai nelayan dalam memenuhi kebutuhan hidup membantu orangtuanya, kondisi inilah yang menjadikan rendahnya kesadaran di tingkat generasi muda Padang Seurahet akan pentingnya Pendidikan untuk masa depannya.

Keberadaan UTU dan Sosialisasi perguruan tinggi yang dilakukan oleh pihak Universitas Teuku Umar berlokasikan kampusnya berjarak kurang lebih $10 \mathrm{KM}$ dengan Gampong Padang Seurahe, menjadikan keterbukaan informasi yang diterima oleh masyarakat semakin cepat dan meluas secara merata. Respon yang di berikan oleh masyarakat Gampong Padang Seurahet terhadap keberadaan Universitas Teuku Umar bersifat positif. Sosialisasi ini menjadikan perubahan terhadap sebagian besar masyarakat yang melanjutkan sekolah ke jenjang yang lebih tinggi khususnya masyarakat yang berusia muda. Kesadaran masyarakat pesisir di Padang Seurahet akan pentingnya pendidikan mulai timbul di akibatkan adanya sarana prasarana letak kampus UTU berjarak dekat . sehingga Akses pendidikan lebih mudah di raih, selain itu faktor lingkungan juga sangat mempengaruhi akan pentingnya melanjutkan pendidikan ke jenjang yang lebih tinggi. bahkan beberapa orang lulusan sarjana dari gampong Padang seurahet telah bekerja di kantor desa sebagai staf atau pegawai swasta. Kesadaran dan pola pikir yang tebuka akan pentingnya pendidikan meraih masa depan yang lebih baik telah menciptakan perubahan sosial yang mendorong generasi muda gampong Padang Seurahet untuk berupaya meningkatkan pendidikan dalam kehidupan masyarakat pesisir.

Pendidikan Keagamaan berjalan efektif dengan tersedianya TPA. Pelaksanaan Kegiatan keagamaan di gampong Blang berandang sama juga dengan kegiatan di kebanyakan desa-desa lainnya, bahkan beberapa anak Gampong Padang Seurahet menjadi juara MTQ tingkat Kecamatan Di Gampong Padang Seurahet ini telah berdiri satu Masjid yang sering mengadakan mengadakan Majelis Taklim dan Zikir, diantaranya wirid yasin, marhaban, nasyid, dan lain-lain. Peserta Majelis taklim ini tenaga pengajar berasal dari suka relawan dan teungku-tengku di gampong. Semangat Keagamaan tercermin juga dalam kehidupan sehari-hari masyarakat Padang Seurahet.

Gambar sebaiknya berwarna yang menggunakan resolusi yang baik dengan ukuran yang tidak besar, sehingga ukuran file kecil namun berkualitas atau gambar 
tidak ngeblur. Penomoran gambar mengikuti nomor sub bab dan nomor urutnya. Sementara itu untuk tabel, judul tabel di atas dan nomornya mengikuti nomor sub bab dan nomor urut seperti contoh berikut:

\section{PENUTUP}

Tuliskan Berdasarkan hasil temuan penelitian sebagaimana tersebut di atas maka dapat diambil sebuah kesimpulan bahwa :

Dengan adanya perbedaan karakteristik masyarakat pesisir maupun perdesaan , khususnya pada masyarakat padang seurahet tetap mampu berperan secara aktif untuk mengelola alam dan potensinya demi keseimbangan dalam memperbaiki kualitas hidup dan kualitas lingkungannya walaupun berbeda atau memiliki ragam profesi baik sebagai nelayan maupun petani namun kearifan lokal yang sesuai dengan kawasannya mesti dilestarikan.

Identitas diri dan Sistem Nilai sosial yang tetap terjaga kearifannya menjadi salah satu faktor penting dalam menjaga keutuhan nilai budaya, nilai agama dan nilai kemasyarakatan di gampong Padang Seurahet menjadi tolak ukur keberhasilan dalam mempertahankan jati diri dari status sosial sebagai masyarakat pesisir yang mampu beradaptasi di dalam pergaulan masyarakat perdesaan di gampong Blang Beurandang.

Di dalam bidang pendidikan di perlukan kerja keras dari aparatur gampong untuk lebih intens memberikan penyadaran kepada masyarakat padang seurahet akan pentingnya melakukan pembelajaran di sekolah-sekolah formal,khususnya bagi usia yang masih produktif muda, sehingga di harapkan kedepan para generasi muda mampu bersaing dengan perkembangan ilmu pengetahuan dan teknologi.

Peningkatan Keagamaan perlu ada pemikiran yang lebih maju ,mengingat modal moral yang di perlukan oleh generasi muda sehingga mampu terhindar dari pengaruh lingkungan yang menyimpang,khususnya permasalahan-permasalahan sosial yang tidak dapat menyelesaiannya secara universal dan menyeluruh.

Perlunya peningkatan Model pembangunan ekonomi, lingkungan, penguatan kapasitas masyarakat dan management dalam mengelola sumber daya alam sesuai dengan potensi dan pengalaman yang dimilikinya menuju kehidupan yang lebih mandiri. kemampuan dalam pengelolaan potensi alam secara baik akan mencapai keberhasilan dalam peningkatkan pendapatan keluarga atau pendapatan asli daerah nya, dengan demikian potensi di daerah pertanian maupun pesisir dapat dikembangkan sebagai bagian dari kearifan lokal dalam melakukan pemberdayaan potensi daerah dan penguatan ekonomi yang berbasiskan model pembangunan kerakyatan secara berkelajutan. apa yang menjadi kesimpulan 
Community: Volume 6, nomor 1, April 2020

p-ISSN: 2477-5746 e-ISSN: 2502-0544

\section{DAFTAR PUSTAKA}

Bungin, B. (2012). Analisis Data Penelitian Kualitatif: Pemahaman Filosofis dan Metodologis ke Arah Penguasaan Model Aplikasi. Edisi 1 Ce. Jakarta: PT RajaGrafindo Persada.

Emzir. (2009). Metodologi Penelitian Pendidikan. Jakarta: Pt Raja Grafindo Persada.

Ihromi, T. (2006). Pokok-Pokok Antropologi Budaya. Jakarta: Yayasan Obor Indonesia.

Koentjaraningrat. (2009). Pengantar Ilmu Antropologi. Jakarta: Rineka Cipta.

Ritzer, G. (1992). Sosiologi Ilmu Pengetahuan Berparadigma Ganda, Penyadur: Alimandan. Jakarta: Rajawali Press.

Ritzer, G. D. (2010). Teori Sosiologi Modern. Jakarta: Kencana Prenada Media Group.

Satria, A. (2009). Ekologi Politik Nelayan. Yogyakarta: LKIS.

Syam, N. (2005). Islam Pesisir. Yogyakarta: LKIS.

Wahyuni. (2011). Perubahan Sistem Nilai dan Budaya Dalam Pembangunan. Sulesana Jurnal Wawasan Keislaman, 206-215. 